\title{
PENGARUH KOMBINASI JENIS BAKTERI PROBIOTIK BERBEDA TERHADAP SINTASAN DAN PRODUKSI UDANG WINDU DI TAMBAK SEMI-INTENSIF
}

\author{
Endang Susianingsih, Nurbaya, dan Muharijadi Atmomarsono \\ Balai Penelitian dan Pengembangan Budidaya Air Payau \\ Jl. Makmur Dg. Sitakka No. 129, Maros 90512, Sulawesi Selatan \\ E-mail: e_sisy@yahoo.com ; hari_atmo@yahoo.com
}

(Naskah diterima: 8 Desember 2011; Disetujui publikasi: 15 Oktober 2012)

\begin{abstract}
ABSTRAK
Penelitian dilaksanakan selama 16 minggu bertujuan untuk mengetahui pengaruh kombinasi bakteri probiotik berbeda terhadap sintasan dan produksi udang windu di tambak semi-intensif dengan padat penebaran tokolan 10 ekor $/ \mathrm{m}^{2}$. Tiga kombinasi bakteri probiotik yang diuji adalah: A) Kombinasi bakteri probiotik A (BL542+ MR55+BT951); B) Pergiliran bakteri probiotik BL542 pada bulan I, MR55 bulan II, BT95 1 bulan III, dan BL542 bulan IV; dan (C) Pergiliran bakteri probiotik BT951 pada bulan I, MY 1112 bulan II, BL542 bulan III, dan BT951 bulan IV. Masing-masing perlakuan diulang tiga kali dalam Rancangan Acak Lengkap (RAL). Penelitian menggunakan 9 petak tambak di Instalasi Tambak Percobaan (ITP) Marana, Maros yang berukuran $25 \mathrm{~m} \times 10 \mathrm{~m}$, yang masing-masing diaerasi dengan blower supercharge. Hasil penelitian menunjukkan, bahwa sintasan dan produksi udang windu tertinggi dicapai pada perlakuan probiotik C (76,6\% dan 484,5 kg/ha), diikuti perlakuan probiotik B (56,2\% dan 440,0 kg/ha), dan probiotik A $(58,8 \%$ dan $320,8 \mathrm{~kg} / \mathrm{ha})$, namun secara statistik ketiga perlakuan ini berbeda tidak nyata $(P>0,05)$. Relatif tingginya sintasan udang windu pada penelitian ini terkait dengan kemampuan bakteri probiotik dalam menekan jumlah bakteri Vibrio spp., kandungan Total Ammonium Nitrogen (TAN) dan nitrit-nitrogen air tambak.
\end{abstract}

KATA KUNCl: kombinasi, bakteri probiotik, sintasan, produksi, dan udang windu

ABSTRACT: Effect of different combinations of probiotic bacteria on survival rate and production of tiger shrimp in semi-intensive brackishwater pond. By: Endang Susianingsih, Nurbaya, and Muharijadi Atmomarsono

This experiment was aimed at knowing the effect of different combinations of probiotic bacteria on survival rate and production of reared tiger shrimp stocked with $10 \mathrm{PLs} / \mathrm{m}^{2}$. This experiment was carried out in completely randomized design using nine $250 \mathrm{~m}^{2}$ experimental ponds of the Research Intitute for Coastal Aquaculture in Marana, Maros for three treatments and three replications each. The treatments tested were: A) Combination of probiotic bacteria (BL542+MR55+BT951) applied weekly; B) Use of probiotic bacteria alternately (BL542 for the $1^{\text {st }}$ month, MR55 for the $2^{\text {nd }}$ month, BT951 for the $3^{\text {rd }}$ month, and BL542 for the $4^{\text {th }}$ month); C) Use of probiotic bacteria alternately (BT951 for the $1^{\text {st }}$ month, MY1112 for the $2^{\text {nd }}$ month, BL542 for the $3^{\text {rd }}$ month, and BT951 for the $4^{\text {th }}$ month). After 16-week application, the results showed that the best survival rate and production of tiger shrimp was achieved by probiotic $C(76.6 \%$ and $484.5 \mathrm{~kg} / \mathrm{ha})$, followed by probiotic B $(56.2 \%$ and $440.0 \mathrm{~kg} / \mathrm{ha})$ and 
combination of probiotic $A(58.8 \%$ and $320.8 \mathrm{~kg} / \mathrm{ha})$, but there were no significantly different among them $(P>0.05)$. These relatively high survival rates for the over all were mainly caused by the ability of the applied probiotics in controlling Vibrio spp., Total Ammonium Nitrogen, and nitrite-nitrogen in the cultured media.

\section{KEYWORDS: combination, probiotic bacteria, survival rate, production, tiger shrimp}

\section{PENDAHULUAN}

Telah dua dekade budidaya udang windu di tambak mengalami keterpurukan dengan berbagai kasus kematian udang, baik akibat lingkungan perairan yang kurang mendukung maupun adanya serangan penyakit bakterial (terutama Vibrio harveyi) dan viral (MBV, YHV, HPV, dan WSSV). Hal ini terjadi bukan hanya di Indonesia (Atmomarsono et al., 1995; Atmomarsono, 2004) namun juga di beberapa negara lain, seperti Thailand Jiravanichpaisal et at., 1994; Pasharawipas et al., 1998; Chanratchakool \& Limsuwan, 1998), Filipina (Lavilla-Pitogo et al., 1992; Albaladejo et al., 1998), India (Vaseeharan et al., 2003), Jepang (Itami et al., 1998), dan Amerika (Lightner et al., 1992; Dhar et al., 2001).

Penggunaan antibiotika untuk penanggulangan penyakit vibriosis pada udang windu seringkali tidak efektif lagi, bahkan juga menimbulkan resistensi bakteri target (Vibrio harveyi) terhadap beberapa jenis antibiotik. Oleh karena itu, Kementerian Kelautan dan Perikanan Republik Indonesia sudah secara tegas melarang penggunaan antibiotika untuk penanggulangan penyakit udang windu.

Metode pencegahan penyakit udang windu melalui pengelolaan limbah budidaya udang menggunakan tandon dan biofilter juga telah dirintis beberapa tahun lalu dan masih terus disempurnakan cara aplikasinya (Muliani et al., 1998; Atmomarsono, 2004). Namun demikian hasilnya belum sesuai yang diharapkan. Oleh karena itu, diperlukan alternatif upaya dalam penanggulangan penyakit udang melalui pemanfaatan bakteri probiotik yang bersifat non patogen dan memiliki kemampuan menghambat dan membunuh bakteri patogen, serta dapat berfungsi sebagai bakteri pengurai dan penetralisir kualitas air (Poernomo, 2004). Sumber bakteri probiotik yang telah diteliti antara lain berasal dari air dan sedimen laut, karang, air, dan sedimen tambak, serta daun mangrove dan makroalga (Tjahyadi et al., 1994; Rosa et al., 1997; Haryanti et al., 2000; Muliani et al., 2003; 2004; Atmomarsono et al., 2009).
Penggunaan bakteri probiotik untuk penanggulangan penyakit udang memiliki beberapa keuntungan seperti: 1) lebih aman daripada berbagai bahan kimia; 2) tidak patogen terhadap ikan/udang; 3) tidak terakumulasi dalam rantai makanan; 4) adanya proses reproduksi yang dapat mengurangi pemakaian berulang; 5) jarang menimbulkan resistensi bagi organisme sasaran; 6) dapat dipakai untuk pengendalian secara bersamasama dengan cara proteksi yang lain. Bakteri probiotik asal tambak yang dikombinasikan dengan bakteri asal laut dan mangrove, diharapkan dapat lebih efektif dalam menanggulangi penyakit pada budidaya udang. Hasil penelitian tahun 2009 (Atmomarsono et al., 2010) menunjukkan bahwa aplikasi bakteri probiotik secara pergiliran (BT951 bulan I, MY1 112 bulan II, BL542 bulan III, dan BT951 bulan IV) menghasilkan sintasan $(66,35 \%)$ dan produksi udang windu $(448,7 \mathrm{~kg} / \mathrm{ha} / 90$ hari) lebih baik daripada kontrol (39,8\% dan 228,7 $\mathrm{kg} / \mathrm{ha} / 90$ hari) maupun aplikasi kombinasi bakteri secara bersamaan pada budidaya udang semi-intensif dengan padat penebaran $10 \mathrm{ekor} / \mathrm{m}^{2}$. Penelitian ini ditujukan untuk mengetahui kombinasi jenis bakteri probiotik yang tepat untuk memperbaiki kualitas air tambak agar bakteri patogen tidak berkembang, sehingga sintasan dan produksi udang windu dapat lebih ditingkatkan lagi.

\section{BAHAN DAN METODE}

Penelitian ini dilakukan di Instalasi Tambak Percobaan Marana, Maros dengan menggunakan 9 petak tambak $250 \mathrm{~m}^{2}$ yang diset dalam Rancangan Acak Lengkap (RAL) dengan 3 perlakuan dan 3 ulangan, yaitu: A) Kombinasi bakteri probiotik A (BL542 + MR55 + BT951); B) Pergiliran bakteri probiotik BL542 pada bulan I, MR55 bulan II, BT951 bulan III, dan BL542 bulan IV; dan (C) Pergiliran bakteri probiotik BT95 1 pada bulan I, MY1 112 bulan II, BL542 bulan III, dan BT95 1 bulan IV (Kontrol probiotik terbaik tahun 2009). Hewan uji yang digunakan berupa tokolan udang windu PL-42 yang sebelumnya telah diuji dengan PCR (tidak 
terinfeksi WSSV) sebanyak 10 ekor $/ \mathrm{m}^{2}$. Kesembilan petak tambak diaerasi dengan menggunakan blower supercharge. Udang diberi pakan berupa pelet sebanyak $50 \%$ dari biomassa total/hari pada awal penebaran dan menurun hingga $2 \%$ dari biomassa total/hari pada minggu terakhir.

Pemberian bakteri probiotik dilakukan setiap minggu yang dimulai sejak minggu kedua setelah penebaran tokolan udang windu hingga panen (minggu XVI). Bakteri probiotik diberikan setelah dilakukan fermentasi selama 4-5 hari dengan menggunakan campuran media berupa tepung dedak ( 1.000 $\mathrm{g})$, tepung ikan $(400 \mathrm{~g})$, ragi (yeast, $100 \mathrm{~g}$ ), molase $(500 \mathrm{~g})$, dan dimasak dengan air tambak (20 L) (Poernomo, 2004).

Pengamatan terhadap jumlah bakteri total (total bacterial count, TPC) dalam air dan sedimen tambak dilakukan setiap dua minggu dengan cara membiakkannya pada media Tryptic Soy Agar (TSA) dalam cawan petri. Sedangkan jumlah Vibrio spp. (total vibrio count, TBV) dalam air dan sedimen tambak dilakukan setiap dua minggu dengan menggunakan media Thiosulphate Citrate Bile-salt Sucrose Agar (TCBSA) dalam cawan petri (Austin, 1987; Buller, 2004). Data bakteri disajikan dalam bentuk tabel dan grafik.

Pengamatan terhadap kualitas air tambak yang meliputi kandungan bahan organik total (BOT), total ammonium nitrogen (TAN), nitritnitrogen $\left(\mathrm{NO}_{2}-\mathrm{N}\right)$, dan nitrat-nitrogen $\left(\mathrm{NO}_{3}-\mathrm{N}\right)$ dilakukan setiap dua minggu bersamaan dengan pengamatan bakteri di atas menggunakan metode standar Boyd (1990) dan American Public Health Association (APHA, 1995). Sedangkan pemantauan terhadap perubahan suhu air, salinitas, $\mathrm{pH}$ air, dan alkalinitas total, serta kandungan oksigen terlarut dilakukan lebih sering lagi (setiap minggu dan pada saat diperlukan) (APHA, 1995). Data kualitas air disajikan dalam bentuk tabel dan grafik, serta nilai kisarannya.

Sintasan dan produksi udang windu diamati pada akhir penelitian (akhir minggu XVI). Sintasan dan produksi udang windu dianalisis ragamnya dan dilanjutkan dengan uji Beda Nyata Terkecil apabila terdapat perbedaan nyata (Steel \& Torrie, 1981). Apabila tidak terdapat perbedaan yang nyata, maka pembahasan diarahkan pada kecenderungan hasil dari rata-rata ketiga perlakuan yang dicobakan.

\section{HASIL DAN BAHASAN}

\section{Populasi Bakteri Vibrio spp. (TBV)}

Total bakteri Vibrio spp. (TBV) dalam air pemeliharaan udang windu selama penelitian disajikan pada Gambar 1. Pada gambar tersebut terlihat bahwa total bakteri Vibrio spp. dalam air pemeliharaan udang windu pada perlakuan A (kombinasi bakteri BL542+MR55+BT951) cenderung lebih tinggi daripada perlakuan $B$ (pergiliran bakteri probiotik BL542 bulan I, MR55 bulan II, BT951 bulan III, BL542 bulan IV) dan perlakuan C (pergiliran bakteri probiotik BT95 1 bulan I, MY1 112 bulan II, BL542 bulan III, BT951 bulan IV). Pada akhir penelitian, jumlah bakteri Vibrio spp. dalam air tambak perlakuan A sekitar $4,13 \times 10^{3} \mathrm{CFU} / \mathrm{mL}$ sedikit lebih banyak daripada perlakuan $\mathrm{B}\left(1,54 \times 10^{3} \mathrm{CFU} /\right.$ $\mathrm{mL}$ ) maupun perlakuan $\mathrm{C}\left(1,08 \times 10^{3} \mathrm{CFU} / \mathrm{mL}\right)$, sedangkan jumlah bakteri Vibrio spp. di petak tandon $\mathrm{T}$ hanya $2,0 \times 10^{2} \mathrm{CFU} / \mathrm{mL}$. Hal ini menunjukkan bahwa jumlah bakteri Vibrio spp. dalam air tambak pemeliharaan udang memang cenderung mengalami peningkatan dibandingkan di petak tandon yang tidak ada udangnya. Hal ini wajar saja, karena di petakan yang ada udangnya tentu mengalami peningkatan jumlah sisa pakan dan kotoran udang yang dapat memicu peningkatan jumlah bakteri. Namun demikian dengan aplikasi bakteri probiotik Balai Penelitian dan Pengembangan Budidaya Air Payau (BPPBAP=RICA) ternyata mampu mengendalikan jumlah bakteri tersebut. Dengan demikian dapat dikatakan, bahwa perlakuan pergiliran bakteri probiotik $C$ lebih baik dalam mengendalikan Vibrio spp. daripada perlakuan A dan B (Gambar 1). Hasil ini sesuai dengan yang dikemukakan oleh Atmomarsono et al. (2009), bahwa aplikasi bakteri probiotik BL542 (Pseudoalteromonas sp.) yang berasal dari laut mampu menekan perkembangbiakan bakteri Vibrio spp. Dalam penelitian ini pemberian bakteri tersebut secara pergiliran memiliki kemampuan yang lebih baik daripada diberikan secara bersamaan dengan bakteri probiotik jenis yang lain. Schulze et al. (2006) juga melaporkan, bahwa aplikasi bakteri Pseudoalteromonas undina yang berasal dari laut juga dapat menekan perkembangbiakan bakteri dan virus patogen pada budidaya ikan dan krustase. Selanjutnya Muliani et al. (2011) melaporkan bahwa penggunaan isolat bakteri BT951 asal tambak (Brevibacillus laterosporus) juga dapat menekan perkembangbiakan bakteri Vibrio spp. 


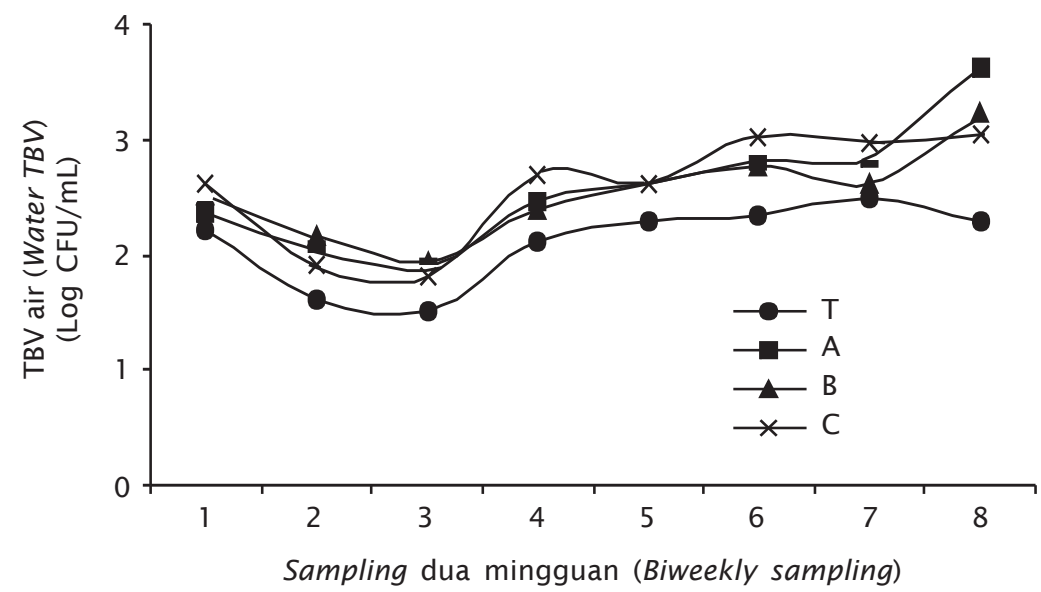

Keterangan (Note): $\mathrm{T}$ = Petak tandon (Reservoir pond); $\mathrm{A}=$ Tambak udang yang diberi kombinasi bakteri probiotik (Shrimp ponds given with probiotic bacteria of BL542+MR55+BT951); B = Tambak udang yang diberi pergiliran bakteri probiotik (Shrimp ponds given with probiotic bacteria of BL542 (1 $1^{\text {st }}$ month), MR55 ( $2^{\text {nd }}$ month), BT951 (3rd month), and BL542 ( $4^{\text {th }}$ month); $C=$ Tambak udang yang diberi pergiliran bakteri probiotik (Shrimp ponds given with probiotic bacteria of BT951 (1 ${ }^{\text {st }}$ month), MY1 112 (2 $2^{\text {nd }}$ month), BL542 (3 ${ }^{\text {rd }}$ month), and BT951 (4 $4^{\text {th }}$ month)

Gambar 1. Fluktuasi kandungan total bakteri Vibrio spp. (TBV) dalam air tambak selama penelitian aplikasi bakteri probiotik di ITP Marana dengan padat penebaran 10 ekor/ $\mathrm{m}^{2}$ yang di-sampling tiap dua minggu

Figure 1. Biweekly fluctuation of TBV of the pond waters during application of probiotic bacteria for tiger shrimp ponds stocked with $10 \mathrm{PLs} / \mathrm{m}^{2}$

Dengan demikian dapat dikatakan, bahwa relatif rendahnya kandungan Vibrio spp. dalam media pemeliharaan udang disebabkan adanya masukan dua jenis bakteri probiotik di atas (BT951 dan BL542). Secara umum kandungan bakteri Vibrio spp. ini masih aman bagi hewan (udang) yang dibudidayakan, karena Olafsen et al. (1993) dalam Buller (2004) melaporkan, bahwa tiram oyster akan sakit apabila kandungan Vibrio spp. dalam hemolymphnya mencapai $10^{5} \mathrm{CFU} / \mathrm{mL}$. Beberapa peneliti lain menyatakan, bahwa kandungan Vibrio spp. dalam hemolymph yang mencapai $10^{5} \mathrm{CFU} /$ $\mathrm{mL}$ disebut sebagai "quorum sensing" yaitu jumlah bakteri yang dapat menyebabkan terjadinya penyakit pada hewan akuatik (Moriarty, 1998; Defoirdt et al., 2004).

Pada Gambar 2 terlihat, bahwa jumlah bakteri Vibrio spp. pada sedimen tambak sekitar $10^{3} \mathrm{CFU} / \mathrm{g}$ pada awal penelitian dan meningkat menjadi sekitar $10^{5} \mathrm{CFU} / \mathrm{g}$ pada akhir penelitian. Hal ini diduga karena adanya peningkatan akumulasi bahan organik di dasar tambak yang memicu peningkatan jumlah bakteri Vibrio spp. yang secara alami tumbuh dengan cara memanfaatkan bahan organik yang ada. Bakteri ini tergolong bakteri anaerobik fakultatif, yaitu bakteri yang tumbuh lebih baik pada kondisi anaerob (kurang oksigen) daripada kondisi aerob (banyak oksigen). Pada kondisi bahan organik meningkat di dasar tambak, proses penguraiannya dapat menimbulkan kondisi anaerob, yang pada akhirnya memicu perkembangbiakan Vibrio spp. Kandungan bakteri Vibrio spp. dalam sedimen ini masih aman bagi udang yang dipelihara, karena masih di bawah kandungan bakteri sedimen yang dilaporkan Garland et al. (1983) dalam Buller (2004) yang dapat mencapai 107-108 CFU/g.

\section{Populasi Bakteri Total (TPC)}

Populasi bakteri total (total bacterial count atau biasa disebut sebagai total plate count = TPC) dalam air (Gambar 3) dan sedimen (Gambar 4) tambak pemeliharaan udang windu selama penelitian. Pada gambar tersebut terlihat bahwa total bakteri dalam air tambak cenderung menurun dari sekitar $10^{8} \mathrm{CFU} / \mathrm{mL}$ pada awal penelitian menjadi sekitar $10^{5} \mathrm{CFU} / \mathrm{mL}$ pada akhir penelitian. Demikian pula halnya terjadi pada total bakteri pada sedimen tambak juga mengalami penurunan dari sekitar $10^{9}$ CFU/g pada awal penelitian menjadi sekitar $10^{7} \mathrm{CFU} / \mathrm{g}$ pada akhir penelitian. Hal ini 


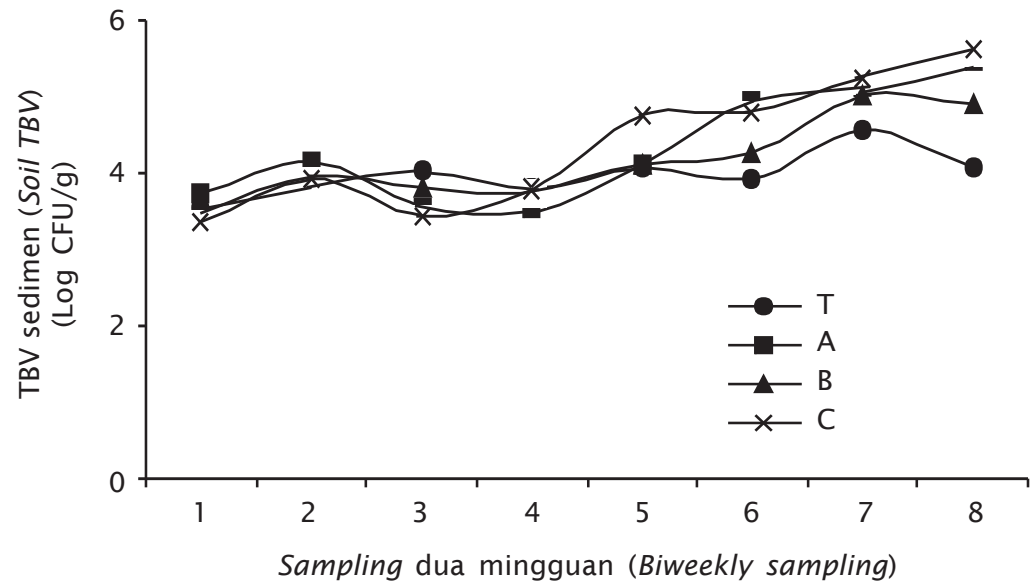

Keterangan (Note): $\mathrm{T}=$ Petak tandon (Reservoir pond); $\mathrm{A}=$ Tambak udang yang diberi kombinasi bakteri probiotik (Shrimp ponds given with probiotic bacteria of BL542+MR55+BT951); B = Tambak udang yang diberi pergiliran bakteri probiotik (Shrimp ponds given with probiotic bacteria of BL542 (1 $1^{\text {st }}$ month), MR55 ( $2^{\text {nd }}$ month), BT951 ( $3^{\text {rd }}$ month), and BL542 ( $4^{\text {th }}$ month); $C=$ Tambak udang yang diberi pergiliran bakteri probiotik (Shrimp ponds given with probiotic bacteria of BT951 (1 ${ }^{\text {st }}$ month), MY1 112 (2 ${ }^{\text {nd }}$ month), BL542 (3rd month), and BT95 1 (4 $4^{\text {th }}$ month)

Gambar 2. Fluktuasi kandungan total bakteri Vibrio spp. (TBV) dalam sedimen tambak selama penelitian aplikasi bakteri probiotik di tambak udang windu dengan padat penebaran $10 \mathrm{ekor} / \mathrm{m}^{2}$ yang di-sampling tiap dua minggu di ITP Marana, Maros

Figure 2. Biweekly fluctuation of the pond sediment TBV during application of probiotic bacteria for tiger shrimp ponds stocked with $10 \mathrm{PLs} / \mathrm{m}^{2}$ in Marana, Maros

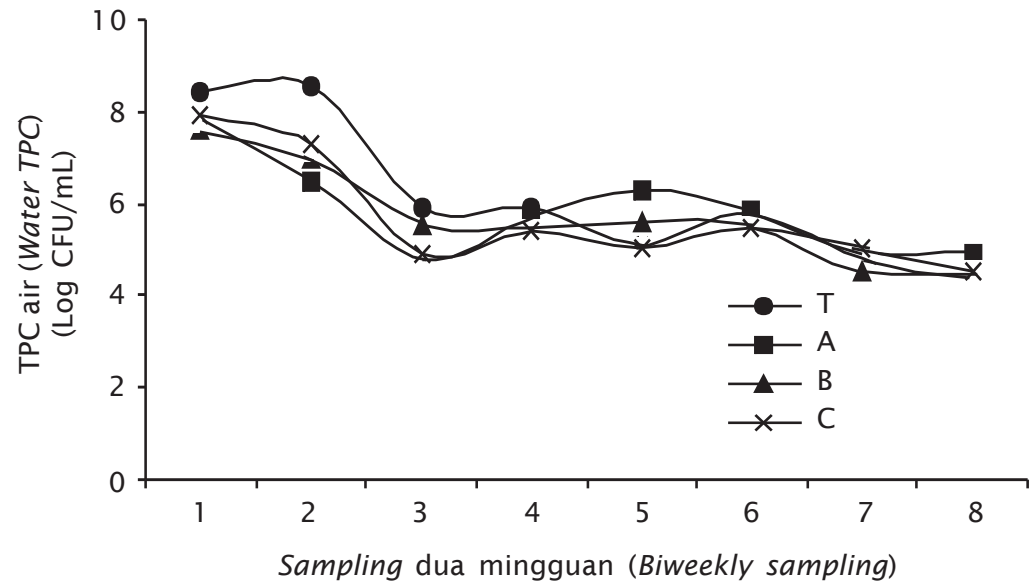

Keterangan (Note): $\mathrm{T}=$ Petak tandon (Reservoir pond); $\mathrm{A}=$ Tambak udang yang diberi kombinasi bakteri probiotik (Shrimp ponds given with probiotic bacteria of BL542+MR55+BT951); B = Tambak udang yang diberi pergiliran bakteri probiotik (Shrimp ponds given with probiotic bacteria of BL542 (1 ${ }^{\text {st }}$ month), MR55 ( $2^{\text {nd }}$ month), BT951 (3rd month), and BL542 ( $4^{\text {th }}$ month); C = Tambak udang yang diberi pergiliran bakteri probiotik (Shrimp ponds given with probiotic bacteria of BT951 ( $1^{\text {st }}$ month), MY1 112 (2 ${ }^{\text {nd }}$ month), BL542 ( $3^{\text {rd }}$ month), and BT951 (4 ${ }^{\text {th }}$ month)

Gambar 3. Fluktuasi populasi bakteri total (TPC) dalam air tambak selama penelitian aplikasi bakteri probiotik di ITP Marana dengan padat penebaran $10 \mathrm{ekor} / \mathrm{m}^{2} \mathrm{yang} \mathrm{di}-$ sampling tiap dua minggu

Figure 3. Biweekly fluctuation of TPC of the pond waters during application of probiotic bacteria for tiger shrimp ponds stocked with $10 \mathrm{PLs} / \mathrm{m}^{2}$ 


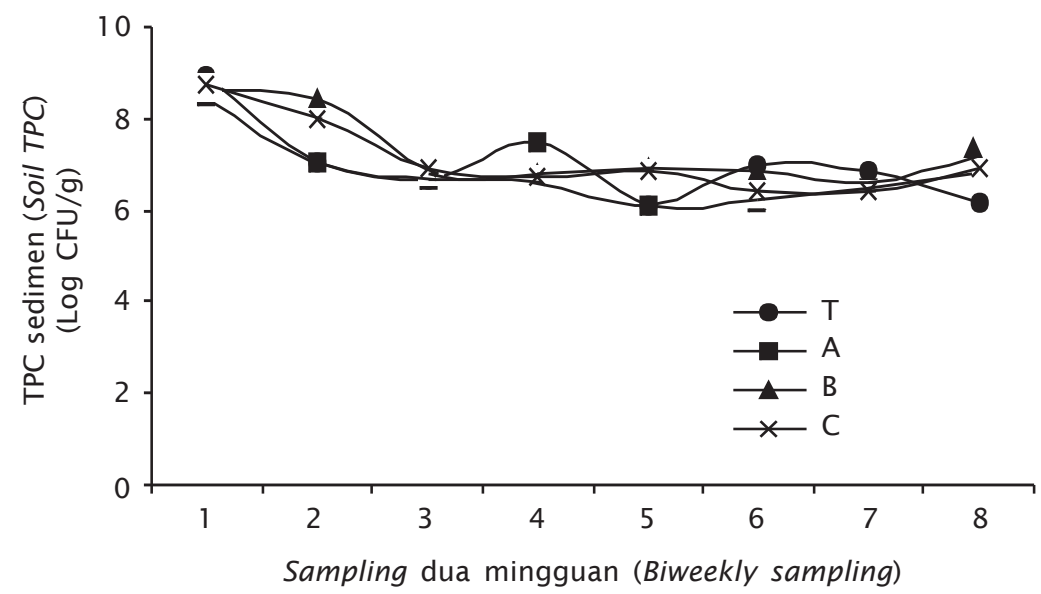

Keterangan (Note): $\mathrm{T}$ = Petak tandon (Reservoir pond); $\mathrm{A}=$ Tambak udang yang diberi kombinasi bakteri probiotik (Shrimp ponds given with probiotic bacteria of BL542+MR55+BT951); B = Tambak udang yang diberi pergiliran bakteri probiotik (Shrimp ponds given with probiotic bacteria of BL542 (1 $1^{\text {st }}$ month), MR55 ( $2^{\text {nd }}$ month), BT951 (3rd month), and BL542 (4 $4^{\text {th }}$ month); $C=$ Tambak udang yang diberi pergiliran bakteri probiotik (Shrimp ponds given with probiotic bacteria of BT951 (1 $1^{\text {st }}$ month), MY1 112 (2 $^{\text {nd }}$ month), BL542 (3 ${ }^{\text {rd }}$ month), and BT951 (4th month)

Gambar 4. Fluktuasi populasi bakteri total (TPC) dalam sedimen tambak selama penelitian aplikasi bakteri probiotik di tambak udang windu dengan padat penebaran 10 ekor/m² $\mathrm{m}^{2}$ ang di-sampling tiap dua minggu

Figure 4. Biweekly fluctuation of the pond sediment TPC during application of probiotic bacteria for tiger shrimp ponds stocked with $10 \mathrm{PLs} / \mathrm{m}^{2}$

menunjukkan, bahwa aplikasi bakteri probiotik BPPBAP (RICA) baik pada perlakuan A, B, ataupun $C$ mampu mengendalikan jumlah populasi bakteri yang ada dalam air dan sedimen tambak di lokasi penelitian.

Tingginya jumlah total bakteri (TPC) pada awal penelitian diduga karena memang aplikasi bakteri probiotik baru dilakukan pada minggu kedua setelah penebaran tokolan udang windu. Setelah aplikasi bakteri probiotik, terlihat bahwa jumlah bakteri mengalami penurunan dari waktu ke waktu. Secara umum kandungan total bakteri dalam air (sekitar $10^{5} \mathrm{CFU} / \mathrm{mL}$ ) dan sedimen tambak (sekitar $10^{7} \mathrm{CFU} / \mathrm{g}$ ) masih berada pada level yang aman untuk budidaya udang, karena masih di bawah kandungan bakteri sedimen yang dilaporkan Garland et al. (1983) dalam Buller (2004) yang dapat mencapai $10^{7}-10^{8} \mathrm{CFU} / \mathrm{g}$. Penggunaan bakteri probiotik RICA (BL542) asal sedimen laut yang teridentifikasi sebagai Pseudoalteromonas sp. Edeep-1 juga dapat menekan perkembangbiakan bakteri lain. Hal ini seperti yang dilaporkan oleh Maeda (1997) dalam Schulze et al. (2006), bahwa pemakaian Pseudoalteromonas undina dapat menekan perkembangbiakan bakteri dan virus patogen.

\section{Kandungan Bahan Organik Total (BOT)}

Kandungan bahan organik total selama penelitian disajikan pada Gambar 5. Pada gambar tersebut terlihat bahwa kandungan BOT berfluktuasi selama penelitian dengan nilai kisaran antara 15-40 mg/L. Kandungan BOT di petak tandon cenderung lebih rendah daripada di petak tambak pemeliharaan udang (perlakuan A, B, dan C). Hal ini wajar saja, karena di petak $A, B$, dan $C$ selalu mendapatkan penambahan bahan organik dari pakan yang diberikan pada udang sistem semi-intensif dengan padat penebaran $10 \mathrm{ekor} / \mathrm{m}^{2}$. Secara keseluruhan kandungan BOT pada semua perlakuan masih cukup layak untuk kehidupan normal udang windu kecuali antara minggu ke10 dan 12 yang mencapai di atas $30 \mathrm{mg} / \mathrm{L}$. Dalam hal ini Madeali et al. (2009) melaporkan, bahwa kandungan BOT dalam air pemeliharaan udang di atas $30 \mathrm{mg} / \mathrm{L}$ dapat meningkatkan patogenesitas bakteri Vibrio spp. Dalam banyak kasus serangan penyakit bintik putih yang disebabkan oleh WSSV (white spot syndrome virus) biasanya terjadi setelah udang dipelihara 40-70 hari. Pada penelitian ini kasus serangan WSSV juga terdeteksi pada minggu 


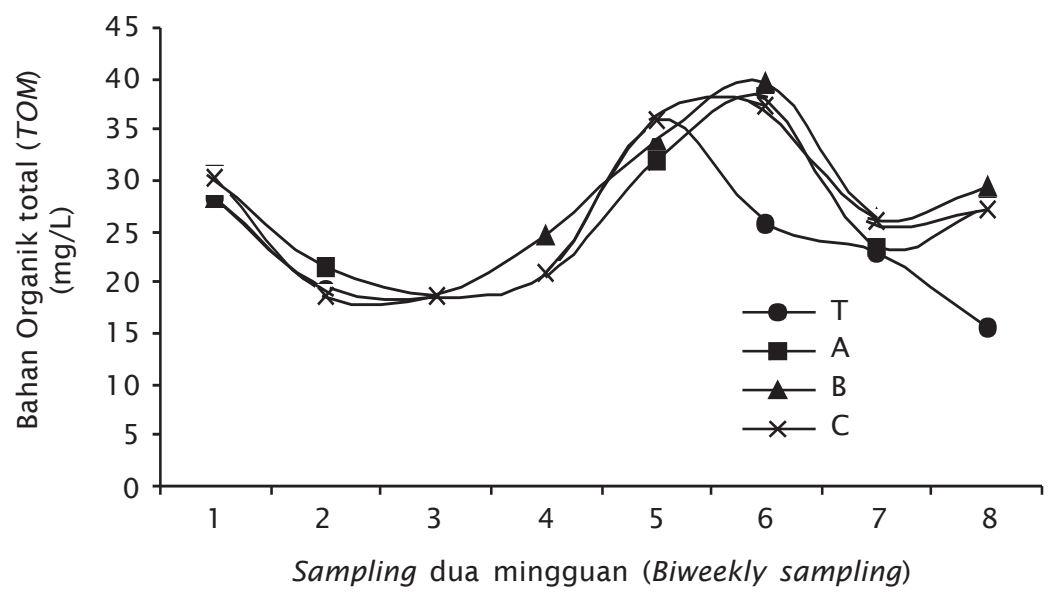

Keterangan (Note): $\mathrm{T}=$ Petak tandon (Reservoir pond); $\mathrm{A}=$ Tambak udang yang diberi kombinasi bakteri probiotik (Shrimp ponds given with probiotic bacteria of BL542+MR55+BT951); B = Tambak udang yang diberi pergiliran bakteri probiotik (Shrimp ponds given with probiotic bacteria of BL542 ( $1^{\text {st }}$ month), MR55 ( $2^{\text {nd }}$ month), BT951 ( $3^{\text {rd }}$ month), and BL542 ( $4^{\text {th }}$ month); $C=$ Tambak udang yang diberi pergiliran bakteri probiotik (Shrimp ponds given with probiotic bacteria of BT951 (1 ${ }^{\text {st }}$ month), MY1 112 (2 ${ }^{\text {nd }}$ month), BL542 (3rd month), and BT951 (4 $4^{\text {th }}$ month)

Gambar 5. Fluktuasi kandungan bahan organik total dalam air tambak udang windu selama penelitian aplikasi bakteri probiotik di Instalasi Tambak Percobaan Marana dengan padat penebaran $10 \mathrm{ekor} / \mathrm{m}^{2}$ yang di-sampling tiap dua minggu

Figure 5. Biweekly fluctuation of total organic matter of the pond waters during application of probiotic bacteria in Marana experimental ponds stocked with $10 \mathrm{PLs} / \mathrm{m}^{2}$

ke-10, yaitu pada petak tambak A1, B3, dan C3. Namun demikian udang windu masih tetap bertahan hidup, karena BOT yang merupakan salah satu pemicu serangan WSSV dapat ditekan kembali oleh adanya aktivitas bakteri probiotik yang diaplikasikan, baik pada perlakuan A, B, maupun C.

Peningkatan kandungan bahan organik total dalam air tambak inilah yang sebenarnya memicu perkembangbiakan bakteri Vibrio spp. seperti yang diperlihatkan pada Gambar 1. Walaupun kandungan bahan organik total dalam air petak $A, B$, dan $C$ relatif sama, namun kandungan total bakteri Vibrio spp. dalam air petak tambak A cenderung lebih banyak daripada petak tambak B dan C. Hal ini diduga karena aktivitas kerja pergiliran bakteri probiotik $C$ dan $B$ lebih baik dalam mengendalikan perkembangbiakan bakteri Vibrio spp. daripada cara pemberian bakteri probiotik secara kombinasi pada perlakuan A (tiga jenis bakteri secara sekaligus).

Kandungan bahan organik total yang tinggi dapat meyebabkan penurunan oksigen secara drastis, karena dipergunakan untuk proses demineralisasinya Boyd (1990). Akibat penurunan oksigen tersebut, maka dapat memicu perkembangan bakteri patogen oportunistik Vibrio harveyi, mengingat bakteri ini tergolong bakteri anaerobik fakultatif (Atmomarsono et al., 2009).

\section{Kandungan Total Ammonium Nitrogen (TAN)}

Yang terukur pada saat penetapan kandungan amoniak dalam air adalah total ammonium nitrogen (TAN), sedangkan nilai kandungan amoniak dihitung berdasarkan $\mathrm{pH}$, suhu, dan salinitas air (Boyd, 1990). Mengingat bahwa nilai kisaran dari ketiga parameter kualitas air tersebut antar perlakuan tidak berbeda jauh pada setiap sampling, sehingga grafik fluktuasi kandungan amoniak $\left(\mathrm{NH}_{3}\right)$ cenderung memiliki pola yang sama dengan grafik fluktuasi kandungan TAN dalam air tambak.

Gambar 6 memperlihatkan fluktuasi dua mingguan kandungan TAN dalam air tambak selama penelitian. Secara umum kandungan TAN dalam air petak tandon $(0,1-0,6 \mathrm{mg} / \mathrm{L})$ jauh lebih tinggi daripada dalam air petak tambak pemeliharaan udang $A, B$, dan $C(0,002$ - 


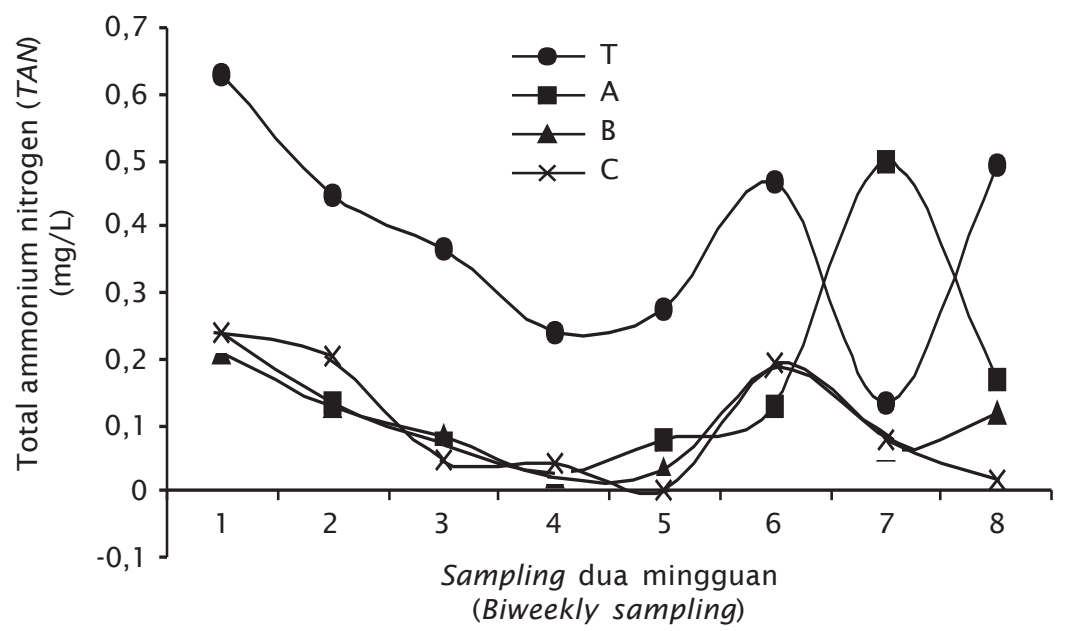

Keterangan (Note): $\mathrm{T}$ = Petak tandon (Reservoir pond); $\mathrm{A}=$ Tambak udang yang diberi kombinasi bakteri probiotik (Shrimp ponds given with probiotic bacteria of BL542+MR55+BT951); B = Tambak udang yang diberi pergiliran bakteri probiotik (Shrimp ponds given with probiotic bacteria of BL542 ( $1^{\text {st }}$ month), MR55 ( $2^{\text {nd }}$ month), BT951 (3rd month), and BL542 ( $4^{\text {th }}$ month); $C=$ Tambak udang yang diberi pergiliran bakteri probiotik (Shrimp ponds given with probiotic bacteria of BT951 ( $1^{\text {st }}$ month), MY 1112 (2 $2^{\text {nd }}$ month), BL542 (3rd month), and BT951 ( ${ }^{\text {th }}$ month)

Gambar 6. Fluktuasi kandungan total ammonium nitrogen (TAN) dalam air tambak selama penelitian aplikasi bakteri probiotik di tambak udang windu dengan padat penebaran 10 ekor $/ \mathrm{m}^{2}$ yang di-sampling tiap dua minggu

Figure 6. Biweekly fluctuation of TAN of the pond waters during application of probiotic bacteria for tiger shrimp ponds stocked with $10 \mathrm{PLs} / \mathrm{m}^{2}$

$0,2 \mathrm{mg} / \mathrm{L}$ ). Pada minggu ke-14 (sampling ketujuh) kandungan TAN dalam air tambak di petak A cukup tinggi (sekitar $0,5 \mathrm{mg} / \mathrm{L}$ ). Sedangkan kandungan TAN terus mengalami penurunan sejak minggu ke-12 (sampling ke6) hingga panen pada perlakuan probiotik $C$ yang lebih rendah daripada dua perlakuan lainnya. Hal ini diduga pergiliran bakteri probiotik C (pergiliran bakteri probiotik BT951 bulan I, MY1 112 bulan II, BL542 bulan III, BT951 bulan IV) selain mampu mengendalikan kandungan bakteri Vibrio spp. juga mampu mengurai bahan organik total (BOT) dan TAN dalam air pemeliharaan udang windu. Secara keseluruhan kandungan amoniak dalam air (yang dihitung dari kandungan TAN pada kisaran suhu $28,7^{\circ} \mathrm{C}-32,5^{\circ} \mathrm{C}$; $\mathrm{pH} 7,2-8,5$; dan salinitas air 24\%-35\%), yaitu kurang dari 5\% dari kandungan TAN ( $<0,01 \mathrm{mg} / \mathrm{L})$ masih aman untuk kehidupan udang windu yang disarankan Atmomarsono (2004). Oleh karena itu, secara keseluruhan amoniak air dalam petakan tambak penelitian ini bukan merupakan stressor yang menekan respons kekebalan udang seperti yang dilaporkan oleh Liu \& Chen (2004).

\section{Kandungan Nitrit-Nitrogen $\left(\mathrm{NO}_{2}-\mathrm{N}\right)$}

Konsentrasi $\mathrm{NO}_{2}-\mathrm{N}$ selama penelitian disajikan pada Gambar 7. Pada Gambar 7 terlihat bahwa konsentrasi $\mathrm{NO}_{2}-\mathrm{N}$ dalam air tandon relatif lebih tinggi daripada dalam air tambak pemeliharaan udang windu pada semua perlakuan (A, B, dan C). Tingginya nitrit dalam air di petak tandon diduga dipengaruhi oleh tingginya kandungan TAN di petak tersebut. Sedangkan tingginya nitrit di petak tambak pemeliharaan udang windu di awal penebaran $(0,189-0,281 \mathrm{mg} / \mathrm{L})$ diduga disebabkan oleh sumber airnya yang memang tinggi kandungan nitritnya (sekitar $0,7 \mathrm{mg} / \mathrm{L}$ ). Selain itu, juga disebabkan oleh kurangnya bakteri pengurai nitrit dalam air tambak tersebut. Hal ini terbukti setelah dimasukkan bakteri probiotik (perlakuan A, B, atau C) mampu mengendalikan kandungan nitrit dalam air hingga berkisar antara 0,017-0,043 mg/L pada akhir penelitian. Hal ini menunjukkan bahwa bakteri probiotik BPPBAP (RICA) mampu menekan nitrit-nitrogen yang merupakan salah satu stressor bagi udang windu di tambak (Chen \& Chin, 1988 dalam Atmomarsono et 


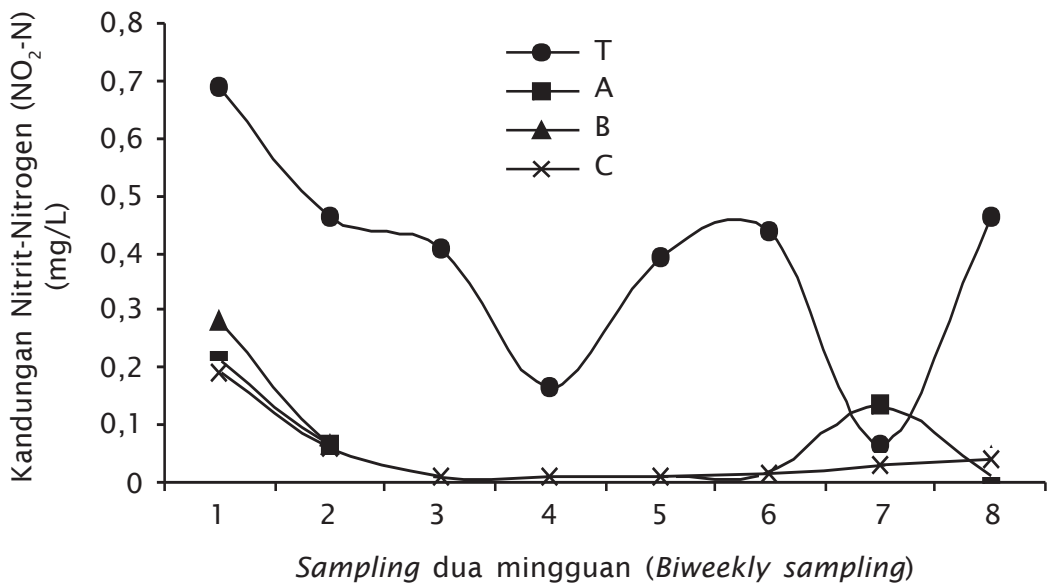

Keterangan (Note): $\mathrm{T}=$ Petak tandon (Reservoir pond); $\mathrm{A}=$ Tambak udang yang diberi kombinasi bakteri probiotik (Shrimp ponds given with probiotic bacteria of BL542+MR55+BT951); B = Tambak udang yang diberi pergiliran bakteri probiotik (Shrimp ponds given with probiotic bacteria of BL542 ( $1^{\text {st }}$ month), MR55 ( $2^{\text {nd }}$ month), BT951 ( $3^{\text {rd }}$ month), and BL542 ( $4^{\text {th }}$ month); $C=$ Tambak udang yang diberi pergiliran bakteri probiotik (Shrimp ponds given with probiotic bacteria of BT951 (1 ${ }^{\text {st }}$ month), MY1 112 (2 ${ }^{\text {nd }}$ month), BL542 (3rd month), and BT95 1 (4 $4^{\text {th }}$ month)

Gambar 7. Fluktuasi kandungan nitrit-nitrogen $\left(\mathrm{NO}_{2}-\mathrm{N}\right)$ dalam air tambak selama penelitian aplikasi bakteri probiotik di tambak udang windu dengan padat penebaran 10 ekor/m² yang di-sampling tiap dua minggu

Figure 7. Biweekly fluctuation of nitrite-nitrogen of the pond waters during application of probiotic bacteria for tiger shrimp ponds stocked with $10 \mathrm{PLs} / \mathrm{m}^{2}$

al., 2009). Kandungan nitrit yang aman untuk pemeliharaan pascalarva udang windu adalah di bawah 4,5 mg/L.

\section{Kandungan Nitrat-Nitrogen $\left(\mathrm{NO}_{3}-\mathrm{N}\right)$}

Konsentrasi nitrat-nitrogen selama penelitian disajikan pada Gambar 8. Pada Gambar 8 terlihat bahwa secara umum konsentrasi $\mathrm{NO}_{3}-\mathrm{N}$ (nitrat-nitrogen) dalam air di petak tandon juga lebih tinggi $(0,029-0,557 \mathrm{mg} / \mathrm{L})$ daripada dalam air petak pemeliharaan udang windu $(0,0025-0,284 \mathrm{mg} / \mathrm{L})$. Namun demikian tingginya konsentrasi nitrat-nitrogen dalam air tambak tidaklah mengganggu udang yang dipelihara, karena nitrat memang bukanlah senyawa beracun seperti nitrit dan amoniak. Nitrat dapat dimanfaatkan secara langsung oleh produser primer dalam tambak (fitoplankton dan klekap) sebagai salah satu sumber nutriennya.

Secara umum konsentrasi nitrat-nitrogen, nitrit-nitrogen, dan total amonium nitrogen dalam air tambak pemeliharaan udang windu maupun di tandonnya masih dalam batas yang aman untuk kehidupan normal udang windu (Boyd, 1990; Atmomarsono, 2004).

\section{Suhu Air, Salinitas, pH, Alkalinitas Total, dan Kandungan Oksigen Terlarut}

Nilai kisaran beberapa parameter kualitas air seperti suhu air, salinitas, $\mathrm{pH}$, alkalinitas total, dan kandungan oksigen terlarut (dissolved oxygen $=\mathrm{DO}$ ) disajikan pada Tabel 1 .

Nilai kisaran suhu air tambak selama penelitian (April-Agustus 2010) masih layak untuk kehidupan udang windu $\left(28,7^{\circ} \mathrm{C}\right.$ $32,5^{\circ} \mathrm{C}$ ). Suhu air tambak yang relatif stabil ini, karena masih seringnya hujan pada saat penelitian yang dilakukan pada musim kemarau ini.

Nilai kisaran salinitas air tambak penelitian juga masih cukup baik untuk kehidupan udang windu $\left(24-35^{\circ} \%\right.$ ), walaupun bukan merupakan kondisi optimumnya $(15-25 \% \%)$. Terjadinya penurunan salinitas air tambak juga akibat hujan yang masih sering terjadi selama penelitian berlangsung. Pada musim kemarau tahun sebelumnya (2009) salinitas air tambak di Instalasi Tambak Percobaan Marana ini mencapai $56 \%$ \%.

Nilai kisaran $\mathrm{pH}$ air tambak selama penelitian $(7,2-8,5)$ berada pada kisaran yang optimum 


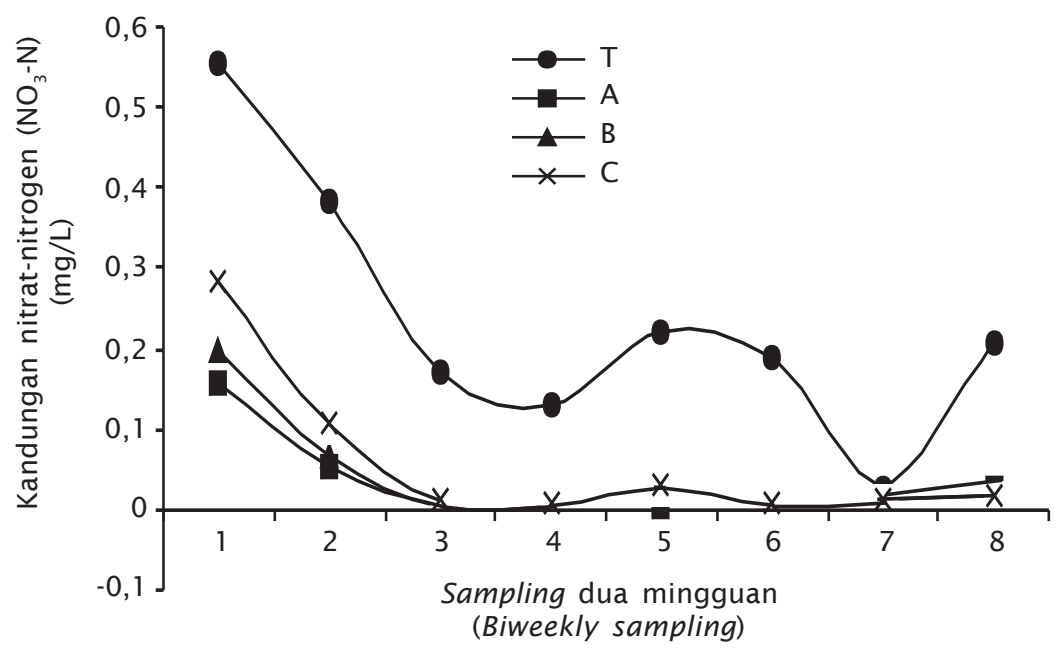

Keterangan (Note): $\mathrm{T}$ = Petak tandon (Reservoir pond); $\mathrm{A}=$ Tambak udang yang diberi kombinasi bakteri probiotik (Shrimp ponds given with probiotic bacteria of BL542+MR55+BT951); B = Tambak udang yang diberi pergiliran bakteri probiotik (Shrimp ponds given with probiotic bacteria of BL542 (1 $1^{\text {st }}$ month), MR55 ( $2^{\text {nd }}$ month), BT951 (3rd month), and BL542 ( $4^{\text {th }}$ month); $C=$ Tambak udang yang diberi pergiliran bakteri probiotik (Shrimp ponds given with probiotic bacteria of BT951 ( $1^{\text {st }}$ month), MY1 112 (2 $2^{\text {nd }}$ month), BL542 (3 ${ }^{\text {rd }}$ month), and BT951 (4 ${ }^{\text {th }}$ month)

Gambar 8. Fluktuasi kandungan nitrat-nitrogen $\left(\mathrm{NO}_{3}-\mathrm{N}\right)$ dalam air tambak selama penelitian aplikasi bakteri probiotik di tambak udang windu dengan padat penebaran 10 ekor/m² yang di-sampling tiap dua minggu

Figure 8. Biweekly fluctuation of nitrate-nitrogen of the pond waters during application of probiotic bacteria for tiger shrimp ponds stocked with $10 \mathrm{PLs} / \mathrm{m}^{2}$

Tabel 1. Nilai kisaran suhu air, salinitas, pH air, alkalinitas total, dan kandungan oksigen terlarut dalam air tambak (DO) selama penelitian aplikasi bakteri probiotik di Instalasi Tambak Percobaan Marana, Maros pada bulan April-Agustus 2010

Table 1. Fluctuation of temperature, salinity, total alkaline, dissolved oxygen of the pond waters during application of probiotic bacteria in the RICA semi-intensif experimental ponds of Marana, Maros (April-August 2010)

\begin{tabular}{lccc}
\hline \multirow{2}{*}{$\begin{array}{c}\text { Parameter kualitas air } \\
\text { Water quality paramet }\end{array}$} & \multicolumn{3}{c}{ Tambak (Pond) } \\
\cline { 2 - 4 } & A & B & C \\
\hline Suhu (Temperature) $\left({ }^{\circ} \mathrm{C}\right)$ & $28.7-32.2$ & $28.8-32.4$ & $28.7-32.5$ \\
Salinitas (Salinity) $\left({ }^{\circ} / \mathrm{o}\right)$ & $24-34$ & $24-34$ & $25-35$ \\
$\mathrm{pH}$ & $7.5-8.5$ & $7.5-8.5$ & $7.2-8.5$ \\
Alkalinitas total (Total alkalinity) & $87.8-155.5$ & $75.2-164.2$ & $92.0-168.5$ \\
(mg CaCO3 eq/L) & $2.7-6.5$ & $3.7-6.5$ & $3.5-7.6$ \\
Oksigen terlarut (Dissolve Oxygen) $(\mathrm{mg} / \mathrm{L})$ & & & \\
\hline
\end{tabular}

Keterangan (Note):

$\mathrm{A}=$ Kombinasi bakteri probiotik BL542+MR55+BT951 (Probiotic bacteria combination BL542+MR55+BT951)

$\mathrm{B}=$ Pergiliran bakteri probiotik BL542 (I), MR55 (II), BT951 (III), BL542 (IV) (Given with bacteria probiotic BL542 (1 ${ }^{\text {st }}$ month), MR55 (2 ${ }^{\text {nd }}$ month), BT95 1 ( $3^{\text {rd }}$ month), BL542 (4 ${ }^{\text {th }}$ month)

$\mathrm{C}=$ Pergiliran bakteri probiotik BT951 (I), MY1 112 (II), BL542 (III), BT951 (IV) (Given with bacteria probiotic BT951 (1 ${ }^{\text {st }}$ month), MY1 112 (2 $2^{\text {nd }}$ month), BL542 (3rd month), BT951 (4 ${ }^{\text {th }}$ month) 
untuk pertumbuhan udang windu seperti yang disarankan oleh Atmomarsono (2004). Nilai pH air ini biasanya berhubungan erat dengan nilai alkalinitas total air tambak. Secara umum nilai alkalinitas total air tambak selama penelitian (83,6-168,5 mg CaCO3 equivalent/L) masih cukup mampu sebagai penyangga $\mathrm{pH}$ air. Namun demikian, alkalinitas total air pada petak tambak B3 pada sampling ke-6 (minggu ke-12) sempat mengalami penurunan hingga 75,2 mg $\mathrm{CaCO} 3$ equivalent/L sebagai akibat tingginya curah hujan. Turunnya alkalinitas total air tambak ini dapat menyebabkan terjadinya goncangan $\mathrm{pH}$ air secara mendadak yang mungkin saja tidak terpantau pada saat penelitian ini berlangsung. Apabila hal ini berlangsung relatif lama, maka dapat membahayakan kehidupan udang windu yang dipelihara (Atmomarsono, 2004).

Kandungan oksigen terlarut dalam air tambak (DO) selama penelitian ini $(2,4-7,6$ $\mathrm{mg} / \mathrm{L})$ masih cukup baik untuk kehidupan udang windu yang dipelihara, walaupun bukan kondisi yang optimum untuk udang. Kandungan oksigen terlarut ini masih dapat terjaga dengan baik, karena adanya aerasi secara terus-menerus dari blower supercharge.
Penggunaan kincir air yang mampu mengaduk air diharapkan dapat meningkatkan sintasan dan pertumbuhan udang windu, karena kandungan oksigen bisa lebih merata ke semua bagian air.

\section{Sintasan dan Produksi Udang Windu}

Sintasan udang windu pada akhir penelitian (minggu ke-16) disajikan pada Tabel 2.

Pada tabel tersebut terlihat bahwa rata-rata sintasan dan produksi udang windu tertinggi pada perlakuan pergiliran bakteri probiotik $C$ (BT951 bulan I, MY1 112 bulan II, BL542 bulan III, BT951 bulan IV), yaitu 76,6\% dan $484 \mathrm{~kg} / \mathrm{ha}$ dibandingkan pada perlakuan B (pergiliran probiotik BL542 bulan I, MR55 bulan II, BT95 1 bulan III, BL542 bulan IV), yaitu 56,2\% dan 440 $\mathrm{kg} / \mathrm{ha}$, maupun pada perlakuan kombinasi bakteri BL542 +MR55+BT951 (58,8\% dan 321 $\mathrm{kg} / \mathrm{ha}$ ). Dengan demikian dapat dikatakan, bahwa pergiliran bakteri probiotik $C$ yang merupakan perlakuan terbaik pada penelitian tahun 2009 masih merupakan kontrol terbaik pada penelitian tahun 2010. Perlakuan pergiliran bakteri probiotik B mungkin dapat digunakan sebagai alternatif apabila probiotik

Tabel 2. Sintasan (\%) dan produksi udang windu ( $\mathrm{kg} / \mathrm{ha}$ ) pada penelitian aplikasi bakteri probiotik di tambak semi-intensif Instalasi Tambak Percobaan Marana, Maros (April-Agustus 2010)

Table 2. Survival rate and production of tiger shrimp cultured with different combination of probiotic bacteria in the RICA semi-intensif experimental ponds of Marana, Maros (April-August 2010)

\begin{tabular}{|c|c|c|}
\hline $\begin{array}{l}\text { Perlakuan (kombinasi bakt eri probiotik) } \\
\text { Treatment (combination of probiotic bacteria) }\end{array}$ & $\begin{array}{l}\text { Sintasan } \\
\text { Survival rate } \\
(\%) \\
\pm S D^{*}\end{array}$ & $\begin{array}{c}\text { Produksi udang } \\
\text { Shrimp production } \\
\text { (kg/ha/16 weeks) } \\
\pm \text { SD" }\end{array}$ \\
\hline $\begin{array}{l}\mathrm{A}=\text { Kombinasi probiotik (BL542 + MR55 + BT951) } \\
A=\text { Probiotic combination of }(\text { BL542 + MR55 + BT951) } \\
\mathrm{B}=\text { Bergantian digunakan bakte ri probiotik } \\
\text { BL542 (I), MR55 (II), BT951 (III), BL542 (IV) }\end{array}$ & $58.83 \pm 36.52^{\mathrm{a}}$ & $320.8 \pm 192.6^{a}$ \\
\hline $\begin{array}{l}B=\text { Alternately used of probiotic bacteria of } \\
B L 542 \text { (I), MR55 (II), BT95I (III), BL542 (IV) }\end{array}$ & $56.15 \pm 12.45^{\mathrm{a}}$ & $440.0 \pm 192.5^{a}$ \\
\hline $\begin{array}{l}\text { C = Bergantian digunakan bakteri probiotik } \\
\text { BT951 (I), MY1 } 112 \text { (II), BL542 (III), BT951 (IV) } \\
\text { C=Alternately used of probiotic bacteria of } \\
\text { BT951 (I), MY1 } 112 \text { (II), BL542 (III), BT951 (IV) }\end{array}$ & $76.56 \pm 5.26^{a}$ & $484.5 \pm 24.9^{a}$ \\
\hline
\end{tabular}


C tidak tersedia. Secara statistik ketiga perlakuan probiotik yang diuji dalam penelitian ini tidak menyebabkan perbedaan nyata $(P>0,05)$ terhadap sintasan dan produksi udang windu.

Terjadinya serangan WSSV pada petak tambak A1, B3, dan C3 pada sebagian udang dalam penelitian ini diduga dipicu oleh adanya peningkatan bahan organik total (BOT) air yang terjadi pada minggu ke-10 akibat turunnya alkalinitas total air pada waktu hujan beberapa hari sebelumnya. Penurunan alkalinitas total air tambak dapat menyebabkan terjadinya goncangan $\mathrm{pH}$ air secara mendadak, sehingga dapat membahayakan udang yang dipelihara. Namun demikian dengan adanya aplikasi bakteri probiotik, udang windu masih tetap bertahan hidup hingga umur panen (minggu ke-16). Pada perlakuan pergiliran probiotik C bahkan masih menghasilkan sintasan $76 \%$ dan produksi udang windu $484 \mathrm{~kg} / \mathrm{ha}$. Hal ini menunjukkan, bahwa aplikasi bakteri probiotik C mampu memperbaiki kualitas air secara cepat (BOT, TAN, dan $\mathrm{NO}_{2}-\mathrm{N}$ ), sehingga mampu mencegah perkembangbiakan bakteri Vibrio spp. maupun virus WSSV.

Dengan stabilnya kualitas air media pemeliharaan akibat aktivitas kerja bakteri probiotik, maka jumlah bakteri Vibrio spp. tidak mampu mencapai "quorum sensing" (berubah menjadi patogen) pada udang windu.

Dengan demikian aplikasi bakteri probiotik memang mutlak diperlukan terutama di tambak semi-intensif yang selalu menambah akumulasi bahan organik di dasar tambak akibat pakan yang tidak dimanfaatkan dan kotoran udang sendiri. Oleh karena itu, makin banyak padat penebaran udang, akan makin banyak pula probiotik diperlukan.

\section{KESIMPULAN DAN SARAN}

1. Pergiliran bakteri probiotik BT951 bulan (I), MY1112 (II), BL542 (III), BT951 (IV) menghasilkan rata-rata sintasan dan produksi udang windu terbaik pada sistem semiintensif di ITP Marana, Maros, yaitu 76,6\% dan $484,5 \mathrm{~kg} / \mathrm{ha} / 16 \mathrm{mg}$.

2. Sintasan udang windu yang tinggi terkait dengan kemampuan bakteri probiotik dalam menekan jumlah bakteri Vibrio spp., kandungan TAN dan nitrit air tambak.

3. Sistem aplikasi probiotik secara pergiliran lebih disarankan daripada kombinasinya secara bersamaan.

\section{DAFTAR ACUAN}

Albaladejo, J.D., Tapay, L.M., Migo, V.P., Alfafara, C.G., Somga, J.R., Mayo, S.L., Miranda, R.C., Natividad, K., Magbanua, F.O., Itami, T., Matsumura, M., Nadala, E.C.B., \& Loh, P.C. 1998. Screening for shrimp viruses in the Philippines. Flegel T.W. (Ed.). Advances in shrimp biotechnology. National Center for Genetic Engineering and Biotechnology, Bangkok, p. 252-253.

American Public Health Association (APHA). 1995. Standard methods for examination of water and waste water. $19^{\text {th }}$ edition. American Public Health Association. Washington DC, 1,082 pp.

Atmomarsono, M., Muliani, \& Ismawati, S. 1995. Prospek penggunaan tandon pada Budidaya udang windu. Makalah disajikan pada "Aplikasi Paket Teknologi di Instalasi Penelitian dan Pengkajian Teknologi Pertanian (IPPTP) Wonocolo, Surabaya 2-4 Juli 1995, $10 \mathrm{hlm}$.

Atmomarsono, M. 2004. Pengelolaan kesehatan udang windu, Penaeus monodon di tambak. Aquacultura Indonesiana, 5(2): 73-78.

Atmomarsono, M., Muliani, \& Nurbaya. 2009. Penggunaan bakteri probiotik dengan komposisi berbeda untuk perbaikan kualitas air dan sintasan pascalarva udang windu. J. Ris. Akuakultur, 4(1): 73-83.

Atmomarsono, M., Muliani, \& Tampangallo, B.R. 2010. Aplikasi bakteri probiotik untuk peningkatan sintasan dan produksi udang windu di tambak. Dalam Sudradjat, A., Rachmansyah, Hanafi, A., Azwar, Z. I., Imron, Kristanto, A. H., Chumaidi, Insan, I. (Eds.). Forum Inovasi Teknologi Akuakultur 2010. Buku I. Pusat Penelitian dan Pengembangan Perikanan Budidaya, Badan Litbang Kelautan dan Perikanan. Jakarta, hlm. 269278.

Austin, B. 1987. Marine microbiology. Cambridge University Press. Cambridge, 222 pp.

Boyd, C.E. 1990. Water Quality in Ponds for Aquaculture. Birmingham Publishing Co, Birmingham, Alabama, USA, 482 pp.

Buller, N.B. 2004. Bacteria from Fish and Other Aquatic Animals: A Practical Identification Manual. CABI Publishing. Oxfordshire, UK, $361 \mathrm{pp}$.

Chanratchakool, P. \& Limsuwan, C. 1998. Application of PCR and Formalin treatment to prevent White Spot Disease in Shrimp. In Flegel TW. (Ed.). Advances in shrimp bio- 
technology. National Center for Genetic Engineering and Biotechnology, Bangkok, p. 287-289.

Defoirdt, T., Boon, N., Bossier, P., \& Verstraete, W. 2004. Disruption of bacterial quorum sensing: an unexplored strategy to fight infections in aquaculture. Aquaculture, 240: 69-88.

Dhar, A.K., Roux, M.M., \& Klimpel, K.R. 2001. Detection and Quantification of infectious hypodermal and hematopoietic necrosis virus and White Spot Syndrome Virus in shrimp using Real-Time quantitative PCR and SYBR green chemistry. Journal of Clinical Microbiology, 39: 2,835-2,845.

Haryanti, Sugama, K., Tsumura, S., \& Nishijima, T. 2000. Vibriostatic bacterium isolated from seawater: Potentiality as probiotic agent in the rearing of Penaeus monodon larvae. Ind. Fish. Res. J., 6: 26-32.

Itami, T., Maeda, M., Suzuki, N., Tokushige, K., Nakagawa, A., Henning, O., Kondo, M., Kasornchandra, J., Hirono, I., Aoki, T., Kusuda, \& Takahashi, Y. 1998. Possible prevention of White Spot Syndrome Virus (WSSV) in kuruma shrimp, Penaeus japonicus, in Japan. In Flegel T.W. (Ed.). Advances in shrimp biotechnology. National Center for Genetic Engineering and Biotechnology, Bangkok.

Jiravanichpaisal, P., Miyazaki, T., \& Limsuwan, C. 1994. Histopathology, biochemistry, and pathogenecity of Vibrio harveyi infecting black tiger prawn Penaeus monodon. J. Aqua. Anim. Health, 6: 27-35.

Lavilla-Pitogo, C.R, Albright, L.J, Paner, M.G, \& Sunaz, N.A. 1992. Studies on the source of luminescent Vibrio harveyi in Peneaus monodon hatcheries. In Shariff, M., Subasinghe, R.P., Arthur, J.R. (Eds.), Diseases in Asian Aquaculture I. Fish Health Section, Asian Fisheries Society, Manila. Philippines, p. 157-164.

Lightner, D.V., Bell, T.A., Redman, R.M., Mohley, L.L., Natividad, J.M., Rukyani, A., \& Poernomo, A. 1992. A review of some major diseases of economic significance in Penaeid prawns/shrimps of the Americas and Indopacific. In Shariff, M., Subasinghe, R.P., Arthur, J.R. (Eds.), Diseases in Asian Aquaculture I. Fish Health Section, Asian Fisheries Society, Manila, Philippines, p. 5780.

Liu, C.H. \& Chen, J.C. 2004. Effect of ammonia on the immune respose of white shrimp
Litopenaeus vannamei and its susceptibility to Vibrio alginolyticus. Fish \& Shellfish Immunology, 16: 321-334.

Madeali, M.I., Atmomarsono, M., Muliani, \& Tompo, A. 2009. Pengaruh konsentrasi bahan organik total (BOT) terhadap patogenesitas bakteri Vibrio alginolyticus pada udang windu. Dalam Djumanto, Dwiyitno, Chasanah, E., Heruwati, E.S., Irianto, H.E., Saksono, H., Yusuf, I.B.L., Basmal, J., Murniyati, Murwantoko, Probosunu, N., Rosmawaty, P., Rustadi, Ustadi (Eds.). Prosiding Seminar Nasional Tahunan VI. Hasil Penelitian Perikanan dan Kelautan Tahun 2009. Jilid II Bioteknologi Perikanan. UGM, Yogyakarta, $6 \mathrm{hlm}$.

Moriarty, D.J.W. 1998. Control of luminous Vibrio species in penaeid aquaculture ponds. Aquaculture, 164: 351-358.

Muliani, Atmomarsono, M., \& Madeali, M.I. 1998. Pengaruh penggunaan kekerangan sebagai biofilter terhadap kelimpahan dan komposisi jenis bakteri pada budidaya udang windu (Penaeus monodon) dengan sistem resirkulasi air. J. Pen. Perik. Indonesia, 3: 54-61.

Muliani, Nurbaya, Atmomarsono, M., \& Tompo, A. 2004. Eksplorasi bakteri tambak dari tanaman mangrove sebagai bakteri probiotik pada budidaya udang windu Penaeus monodon. Laporan hasil Penelitian. Balai Riset Perikanan Budidaya Air Payau, $18 \mathrm{hlm}$.

Muliani, Nurbaya, \& Susianingsih, E. 2011. Karakterisasi dan identifikasi molekuler isolat BT951 serta evaluasi potensinya sebagai bakteri probiotik pada budidaya udang windu (Penaeus monodon). J. Ris. Akuakultur, 6(3): 457-468.

Muliani, Suwanto, A., \& Hala, Y. 2003. Isolasi dan karakterisasi bakteri asal laut Sulawesi untuk biokontrol penyakit vibriosis pada larva udang windu (Penaeus monodon Fab.). Hayati, 10: 6-11.

Pasharawipas, T., Sriurairatana, S., Direkbusarakom, S., Donayadol, Y., Thaikua, S., Ruangpan, L., \& Flegel, T.W. 1998. Luminous Vibrio harveyi associated with tea brown gill syndrome in black tiger shrimp. In Flegel T.W. (Ed). Advances in shrimp biotechnology. National Center for Genetic Engineering and Biotechnology, Bangkok, Thailand, p. 213-216.

Poernomo, A. 2004. Technology of probiotics to solve the problems in shrimp pond cul- 
ture and the culture environment. Paper presented in The National Symposium on Development and Scientific and Technology Innovation in Aquaculture, January 27-29, 2004. Patrajasa Hotel, Semarang, 25 pp.

Rosa, D., Zafran, Taufik, I., \& Girsang, M.A. 1997. Pengendalian Vibrio harveyi secara biologis pada larva udang windu (Penaeus monodon): I. Isolasi bakteri penghambat. J. Penel. Perik. Indonesia, 3: 1-10.

Schulze, A.D., Alabi, A.O., Tattersall-Sheldrake, A.R., \& Miller, K.M. 2006. Bacterial diversity in marine hatchery: Balance between pathogenic and potentially probiotic bacterial strains. Aquaculture, 256: 50-73.
Steel, R.G.D. \& Torrie, J.H. 1981. Principles and Procedures of statistics. Abiometrical Approach ( $2^{\text {nd }}$ edition). International Student Edition. McGraw-Hill International Book Company, 633 pp.

Tjahjadi, M.R., Angka, S.L., \& Suwanto, A. 1994. Isolation and evaluation of marine bacteria for biocontrol of luminous bacterial diseases in tiger shrimp larvae (Penaeus monodon Fab.). Aspac. J. Mol. Biol. Biotechnol., 2: 347-352.

Vaseeharan, B., Jayakumar, R., \& Ramasamy, P. 2003. PCR-base detection of white spot syndrome virus in cultured and captured crustaceans in India. Lett. Appl. Microbiol., 37: 443-447. 